Geliş Tarihi: 05.10.2018

Kabul Tarihi: 04.12.2018
Mediterranean Journal of Humanities mjh.akdeniz.edu.tr VIII/2 (2018) 451-461

\title{
A Post-Colonial Reading of 'Qasr-i Abu Nasr'
}

\author{
'Qasr-ı Abu Nasr' in Post-Kolonyal bir Okumast
}

\section{Roohollah ROOZBEH *}

\begin{abstract}
The Story of "Qasr-i Abu Nasr" (1941), one of the perfect achievements of Hedayat deals with a group of foreign archeologists excavating in Iran. Hedayat deploys archaeological excavation as a metaphor for plundering Iran. To do so he uses an Iranian woman to symbolize Iran. Equally likely, he chooses a real historical site as the setting of his story. Our hypothesis is that Hedayat is against the presence of foreigners in Iran and writes to condemn it. This is evident from stylistic specifics like the tone, setting, irony, and suspense of the story.
\end{abstract}

Anahtar sözcükler: Qasri-i Abu Nasr, Hedyat, Excavation, Pluderning

Öz: Hedayat'ın mükemmel başarılarından biri olan “Qasr-i Abu Nasr”ın (1941) öyküsü, İran'1 kazıyan bir grup Amerikalı arkeologla ilgilidir. Hedayat, İran’1 yağmalamak için bir metafor olarak arkeolojik kazı kullanıyor. Bunu yapmak için İran’ın sembolü olan İranlı bir kadın kullanır. Aynı şekilde, muhtemelen, hikayesinin yerleşimi olarak gerçek bir tarihi alanı seçer. Hipotezimiz, Hedayat'ın İran'daki Amerikalıların varlığına karşı olduğu ve bunu kınamak için yazdığıdır. Bu, hikâyenin tonu, ayarı, ironisi ve sarsılması gibi üslup özelliklerinden açıkça görülmektedir.

Keywords: Qasr-i Abu Nasr, Hedayat, Kazı, Yağma

\section{Introduction}

In his book Before the Roses and Nightingales: Excavations at Qasr-i Abu Nasr, Old Shiraz Donald S. Whitcomb $(1985,7)$ writes:

"The excavations at Qasr-i Abu Nasr were begun in 1932 during the Great Depression in the United States. The trustees of The Metropolitan Museum of Art had cut down on the fieldwork they subsidized in Egypt but took the opportunity to authorize excavations- on a very small scalein Iran. Shah Riza Pahlavi had abrogated the treaty that had given France sole permission to excavate in that country; thus it was possible to further the Museum's interest in Sasanian art and archaeology, which had begun with the joint excavations with the Germans at Ctesiphon in Iraq in 1931-32".

Why does Sadeq Hedayat in his short story "Qasr-i Abu Nasr" (1941), describe Dr. Warner and his archeologist friends who dig in the historical site of Qasr-i Abu Nasr? There can be a plethora of reasons for this question. In the same book, Whitcomb $(1985,11)$ reveals the

* Department of English Language and Literature, Faculty of Literature and Humanities, Vali-e-Asr University of Rafsanjan, Rafsanjan, Iran.r.roozbeh@vru.ac 
intention of Sadeq Hedayat and maintains that:

"In Sadeq Hedayat's short story the excavators go on to discover an ancient Persian mummy, and a typical mummy story unfolds. It is clear chat the setting is the result of a visit to Shiraz and interviews with workmen who had participated on the excavations (who relocated The Metropolitan Museum of Art to Chicago, a city known from the Persepolis excavations). The result is a fascinating view of the excavations as the workmen understood it and a sensitive portrait of the feelings of the three excavators toward their discoveries".

Quite contrary to Whitcomb, this article cogently argues that Hedayat describes a group of archeologists who excavate the historical site of Qasr-i Abu Nasr in order to show his dissatisfaction with the foreign archeologists' presence in Iran, to show that the archeologists are plundering Iran, and lastly to resist colonialization of Iran by writing itself. Hedayat is among writers who make use of innuendos of wit and irony to raise the consciousness of people. His writing, in this regard, is not a translucent straightforwardness of vision and accomplishment from beginning to end, from the surface to its most subterranean complexities. In fact, his short story is such indirect that one should employ a bravura reading to get to the depth and gist of the story. For example, in short story "Fardaa" (Tomorrow), he indirectly makes Zaghi a character to resist against an American soldier who decides to beat an Iranian woman. For intervening with the affairs of the soldier, Zaghi is imprisoned. By identifying with Zaghi, Hedayat gives the reader the clue to understanding Hedayat is dissatisfied with the presence of the foreigners in his country. Hedayat makes it a story indirectly to let the reader understand the foreigners should not be in Iran and of course, this is more effective than telling it directly.

\section{Discussion}

Hedayat chooses an actual ancient site, Qasr-i Abu Nasr, as the setting of his story. Qasr-i Abu Nasr was unearthed under the supervision of foreign archaeologists. Why has Sadeq 'Hedayat chosen this place as the setting of his story? Katouzian $(2002,157)$ maintains it is because of the reason that Hedayat is interested in the ancient Iran. Others believe "the plot of the story is carefully fashioned, and the minutiae show Hedayat's deep interest in the rites and witchcraft of old Iran" (Kamshad 2011, 188). Zarrin (1997, 37) says Hedayat wants to show that "Americans plunder ancient Iranian gems and jewels". In keeping with Zarrin who notes the plundering of ancient Iran, this article demonstrates how Iran is plundered and raped by the archeologists. Hedayat rewrites the history of the Qasr-i Abu Nasr to set it against that of the western one.

The story of Hedayat starts with the following lines:

"It was the second year that the excavations of the Metropolitan Museum of Chicago had made scientific discoveries on the mound of Takht-i Abu Nasr near Shiraz. But other than miserable graves with a few bones, red pots, gorgets, bronze helmets, trilobate arrows, earrings, rings, signet necklaces, bracelets, daggers, coins of Alexander and Heracles, and one large candlestick with three legs, nothing worthy of attention had been found" (Whitcomb 1985, 11).

The story sets the scene: a foreign excavating group is in Qasr-i Abu Nasr do scientific research (italics are mine). Having given a detailed description of the explorations of the Metropolitan Museum of Chicago, Hedayat says they had found nothing significant. The tone of Hedayat in these lines is critical because he tells the reader that the group is looking for something significant 
to benefit enormously from. Then he enumerates what they have found: "bones, red pots, gorgets, bronze helmets, trilobate arrows, earrings, rings, signet necklaces, bracelets, daggers, coins of Alexander and Heracles, and one large candlestick with three legs" (Hedayat 1963, 77). For archeologist anything of the above list is significant from which they will be able to tell the history of a nation. One might ask the right question: What is that significant thing? Hedayat, based on the story, says the significant thing is the discovery of a coffin within which lies the corpse of Simuyeh and contains a letter. While a corpse and a letter can be significant as well for archeologists, when we get down to the whole story and its relationship with the findings of the group, it is the material things in the coffin which are important as Hedayat lays it bare. Then, Hedayat describes the archeologist, Warner and his colleagues choosing names which attract attention: Warner, Freeman and Gorest

\begin{abstract}
"Dr. Warner, who was an archaeologist and specialist in dead languages, tried in vain to investigate history from cylinder seals with cuneiform and animal and/or human forms and from signs on clay jars. Gorest and Freeman, his associates in clothes yellow and dirty, arms and legs bare that were burnt from the rays of the sun, cotton cap on the head and notebooks under their arms, were busy from morn to night directing the workmen, taking notes and photographs" (Whitcomb 1985, 11).
\end{abstract}

Choosing these names is not accidental at all. Hedayat uses name symbolism in the story. The reality of the names sheds light on and endorses the fact that Hedayat accentuates the names to defamiliarize them and wants us to attend to the meaning of the names. The most obvious examples of the ambiguity and irony achieved through the selection of names are the names of Warner, Freeman and Gorest. The word "Warner" in English that means "to warn" means "Hoshdaar" in Persian. Additionally, the name Freeman that means 'to be free' means Azadeh in Persian. Gorest consists of the two verbs 'go' and 'rest'. The names are in accordance with the characters when we analyse the story in the light of Orientalism. Through these names, Hedayat, whose name means true path, wants to give a message. Warner is there to warn his colleagues to watch out when making love to Khorshid to avoid any scandal. Gorest has come to Iran to get rest and pleasure. Freeman is not a freeman on the grounds that he is in Iran plundering the country.

\title{
Digging
}

The story deals with foreign archeologists digging in Qasr-i Abu Nasr. The idea of digging a country by a foreigner to decide the history of that country is not something which a writer like Hedayat must like. On a larger, more metaphoric scale, digging is progressively expanded into an imperial dream. Digging is penetrating. Warner, Freeman, and Gorest excavated Qasr-i Abu Nasr and at the same time have sex with Khorshid and her friends. Since digging is penetrating the land which might be interpreted as female in reference to the concept of "motherland", it is a kind of raping. This is where rape and digging become interchangeable. The archaeologists try to identify and classify the oriental Iran and its geographic conditions, resources, mines, history, ethnicities, language, customs, traditions, habits, culture, beliefs, religions, civilizations, psychological characteristics, and the spiritual sensitivities of Iran with the intention of identifying its material and spiritual riches.

\section{Sadeq Hedayat reveals the scandal by writing.}

There is a kind of scandal in the story as Warner names it. This scandal, according to Warner, is the relationship between Gorest and Khorshid. 
I disagree that with the Miassian car we can go after amusement. We must not forget that we have a great responsibility. Our behavior is under great scrutiny. In these small places, ones' actions are easily noticed! Two days later, either Qasim or any of the workers may say a thousand words against us, I do not want a scandal. I recommend to you this be the last time (Hedayat 1963, 77).

Warner warns Gorest to take a lot of care when meeting Khorshid and not to use the organization's car as people will understand. Warner refers to this love-making and is not seriously against it as he advises Gorest to help him a little and then go to his love-making agenda. There is a point in his warning Gorest. He tells him "after helping them if Gorest likes to, he can go and make love to Iranian girls" (ibid). What is of note here is that Warner warns Gorest not to be seen when he is with Iranian women. If he is seen, this will lead to a scandal. This shows that Warner confirms Gorest's lovemaking, albeit being afraid of a scandal. This provides a focus for a rather clear placing of the archeologists within orientalist ideology. One can say Hedayat reveals Warner's intention and betrays him by writing about them and sharing their secret with the reader. This shows the plundering of Khorshid khanom. Moreover, Warner will also be afraid if Iranian people find out about what the excavating group has discovered. It remains for Hedayat to betray them about what they discover. Thus, there is a kind of rape in the story which is in keeping with the plundering of Iran. On the one hand, Iran is dug and penetrated into, on the other; Khorshid is raped by Gorest and his friends. We can argue that Hedayat has set Iran as a female body that is plundered and raped. The story inculcates the idea that Iran is a woman who is raped. This shows the way the archeologists think about Khorshid khanum and her friends. This finds expression in Gorest's conversation with Warner and Freeman concerning spending time with three women from Shiraz:

It is five months, we live like dogs in this wilderness, and after discovering a notable coffin, I think we have the right to have fun. Am I to blame that I cared for you? I went with the car to Shiraz, and brought three women and with their insisting brought two musicians too. What is strange is the discovery of the coffin that everybody talks about and these women suspect that we have found a lot of treasure and jewelry. In any case, they are, at the moment in Barm-e Delak. They have set up a tent and stay tonight. No one is there, it's okay, are there any glasses of whiskey left? All food is provided, I sent Qassim, to prepare everything (Hedayat 1963, 77).

As it turns out, Gorest has arranged a time of pleasure at which three women were invited to bring joy and happiness to Gorest and his friends. Spending time with or sleeping with Khorshid and her friends is accentuated in this story by Hedayat. This accentuation finds expression in Warner opposition to this recreation, and he believes it is dishonoring for them if they are discovered by Qasem, which must remain hidden from everyone, otherwise, it will lead to a scandal. Gorest assures him no one has noticed anything.

I assure you nobody has seen us. Because they had come out of town, but what is noteworthy is that tonight we have Eastern musical instrument. The singers are Jewish and they only play indigenous instruments. Perhaps it's the same instrument that was played at the time when the village was alive, when Simuyeh lived in his real estate! Let us suppose your old monkey has had three wives by his own, while each of three of 
us will never marry three wives but one wife each. Believe me, we have to live among and associated with the living, but before that, I say to you that Khorshid khanom, who is the youngest of all, will be mine (Hedayat 1963, 98-9).

Gorest describes Khorshid Khanom as follows: "Khorshid Khanom is a tall girl who has shining eyes, round face and black hair. She is one of the oriental beautiful women. You know, first, she chose me and sent me a note (turns his face to Freeman). Do you remember that woman on Sunday in Barm-e Delak, who kept signaling at me?” (Hedayat 1963, 88). This interest of Gorset in Khorshid Khanom and the way he describes her, commodifies Khorshid Khanom as a woman who is beautiful, lissome, lithe, and has shining eyes and black hair. In the story of the "Qasr-i Abu Nasr", Khorshid is a name both in past and present. In the old story, Khorshid is a prostitute and in the present time of the story Khorshid is a prostitute too except that she is now serving Dr. Warner and his friends. This is not something accidental. Khorshid has been repeated in both ancient and modern times of the story, and this repetition can be a motif Hedayat has deliberately inserted in the story. It is noted in these lines that it was Khorshid Khanom who liked Gorest, and this suggests that the western man is attractive to the eastern woman. Gorest places a great deal of emphasis on the immoral vision of a sexually obedient Khorshid. The secret of conquering Iran is conceptualized as penetrating the oriental Khorshid. The imputed relaxed passivity of the Oriental Khorshid Khanom, in contrast to the lively western man motivates a desire to penetrate the women and to dig the oriental Iran.

The encounter can be characterized as an emblematic descriptive mutilation of the love object, and in the culmination of the story's course, this vision freely gives way to Orientalism set forward by Edward Said. Silvia Antosa (2012, 191), examining Richard Burton, cogently argues that 'Orientalist sexuality was founded on a specific representation of women as creatures, who were ready to be objectified by male dominion and control'. Elizabeth Grosz $(1994,208)$ appropriately pays careful attention to how woman becomes an enigma to dominate within safe or unfrightening boundaries. Thus, we can appropriately argue how Iran becomes an enigma for westerners to dominate within safe boundaries. Unquestionably, the text here supports Reina Lewis's $(1996,18)$ argument that 'the European paradigm of sexual difference constructs women as objects of knowledge which secure definitions of a superior masculinity'.

The word "sharqi" meaning "Orient" is often repeated in this story, and one can say that it is one of the motifs of the story. From the repetition of the word "sharqi" in this story, it can be seen that Sadeq Hedayat has presented the binary opposition of West and East. Hedayat shows that Westerners regard the culture of the East as culture of the other and hence confront it strangely. The archeologists develop knowledge of and about Iran that is entirely constructed. To do that the archeologists must excavated the historical places like Qasr-i Abu Nasr to define it.

\section{Benevolence}

Drawing on historical and political imagery, Hedayat's story seems to be such a potent voice against Warner's imperial discourse of benevolence that they want to help Gorandokht to materialize her dreams of taking revenge against Simuyeh. Posited against the fallacy of benevolence, "Qasr-i Abu Nasr" celebrates resistance. This benevolence is shown in the following words:

I know you laugh at me. Do not make mistakes, I am more faithless than you are. But I imagine that this is the will of a woman who, perhaps hundreds years ago, died and believed that her blood had been cast just 
for the sake of the mummified, hoping someday her will shall be read. I would like to say by that, the wishes and desires of a woman are fulfilled whom we owe, we owe her jealousy. It is not too expensive for us, only two types of incense we need that I have already prepared, a few flames of fire and half an hour of energy. It does not cost us anymore. Who knows! ... We have yet to understand the secrets of our predecessors! (Hedayat 1963, 82).

Dr. Warner and his colleagues are after recovering the voice of the Gurandokht through her to write the history of ancient Iran. It is through her will that they find their source of information about ancient Iran. The irony is there in the words of Warner. He is an archeologist who is interested in the textual will of Gorundokht, which is pure superstition. Hedayat shows that Warner contradicts himself as to the nature of archeology. Somewhere else in the story Warner says:

Do you think these prehistoric marbles, for example, from which one can guess that a human lived four thousand years ago near this mountain spring and ate in this bowl are scientific, while he had no direct relationship with our lives? (Hedayat 1963, 82).

Warner himself has come to Iran for excavation and is an archaeologist, and he talks like this in the above lines. Of course, it is logical from bowls and marble to guess that human beings lived where these things were discovered. Basically, the definition of archeology is exactly what he says: one should excavate the earth to find about the ancient people and how they lived and where they lived and in what they ate. So what is the purpose of this kind of jargon? This ancient man who lived in the past is not a fool and should be known about, but here Warner has completely contradicted himself. Of course, this is Hedayat's technique to use irony and show the character of Mr. Warner to the reader. Warner acts in accordance with the whimsy will of Gurandokht, which, he believes, is not scientific and money-making, and is completely entertaining.

Freeman considers the will to be superstitious, and interestingly, Warner sees it as a human and sympathetic tragedy. The will presents Iran as superstitious. Much of the will presents the ancient region as superstitious: "According to popular beliefs, if a man takes a shroud to his teeth, there will be death among the living. In order to avoid disaster, they must explore the cemetery and, after finding the dead bloodthirsty, cut off their head from the body" (Hedayat 1963, 82). Ghanoonparvar (2010, n.p.) believes Hedayat's "treatment of these Western characters appear to be sympathetic ... and he presents through the characters particularly Dr. Warner his own suppositions and in some ways romantic and nostalgic feelings about ancient Iran". If Hedayat is sympathetic towards Dr. Warner and his friends, the will and its interpretation likewise should be taken at face value, which signifies that Hedayat through Warner tries to extract reality out of pure superstition, the repercussions of which might be, on the part of Hedayat, the introduction of Iran as having qualities that are like Africans. This foolish man whom Warner talks about has lived in Iran and is not certainly considered foolish by Hedayat. Dr. Warner and his friends not only seek the fact about the Iranian folly, but also seek the material resources of Iran. According to the inhabitants of the city, they have found a lot of jewels and valuable things "they found lots of gold and jewelry. They split a grave in which were diamonds and jewelry with seven Khosravi caskets" (Hedayat 1963, 98-9).

The story's imagination and the element of suspense which make the reader keep track of the story to the end are highly important. Nevertheless, the ending of the story, which is the upshot of the suspense, is also important. The tremendously eager reader wants to know what happens 
next. The reader likes to see what happens at the end to Simuyeh. Will he say anything from the old world? After being brought to life, Simuyeh goes to Barm-e Delak, calls out the name of Khorshid and having kissed her, disintegrates into ashes. This denouement is not interesting and exciting for the reader. The reason is that this denouement that brings the reader's surprise is the death of Simuyeh. Simuyeh changes into ashes and dies, and tells us nothing of the past. Dr. Warner and his friends take Simuyeh's jewelry with no regard for Simuyeh's death. The end of the story and the denouement do not convince the reader. The enormously enthusiastic Warner, who was so interested in knowing what the news of the old world would be, just records Simuyeh's jewelry. In fact, what is of utmost importance to him is Simuyeh's jewelry:

At the same time, Dr. Warner and Freeman and Gorest with Inga arrived, as they wanted to lift Simuyeh from the ground, they saw that his whole body was breaking down into a handful of dust and a large spot of wine was on his clothes. They took his jewelry, his garments, and his sword, and returned. Dr. Warner scored them carefully at night and recorded them (Hedayat 1963, 98-9).

It is a clear indication of Hedayat's acuity to entertain the reader with the element of suspense to make the reader read through the story and at the end to warn and awaken the reader and to clarify that Warner is seeking to record the gems of the land. Implicitly, Hedayat wants to warn the reader that a Western who considers himself to be logical cannot be interested in the superstitious story of Gorandokht. So in what is the westerner interested? Hedayat's answer is in the jewelry and in presenting Iran as a superstitious country.

The story ends with the verb, 'recorded' and this cannot be accidental and Hedayat has drawn our attention to this verb. The word 'Record' can show that the West captures and seizes all the mines and reserves of Iran in their names. It is not the broken marbles that engage their attention day and night in the desert, but the discovery of Iran's wealth and underground resources which make them perspire in the desert. The Persian verb 'zabt kard' also means 'seized' and 'captured', and it can be said in this statement it also means 'captured' because in the middle of the story, Gorest asks Warner to relinquish the idea of bringing Simuyeh back to life and instead take Simuyeh's jewels, clothing, and sword:

I didn't think it would come to this. Now you have decided to bring the old monkey into life. You think the population of the world is too few! You want to add another person to the population of the world! In this case New York Summoning Ghosts association will give us a token. I thought you were kidding, but now I see this myth has seriously changed your thought. Do you seriously think this skeleton will come to life and tell about its own world? If so, it will be a ridiculous story. But still there is a long time ahead of the day of reckoning. Thus if we take his jewelry it is logical. Then examine if the dead body will come to life or not (Hedayat 1963, 98-9).

Hedayat's tone in the above lines is ironic. Gorest's humour that the population of the world will be too many if Simuyeh is added to it is a black one. When Gorest finds he cannot persuade Warner to quit bringing Simuyeh back to life, he says: "so, at least, disarm him and remove his sword so that he will not kill us if he comes to life again. However, I suggest we should take the jewelry with us" (ibid). The emphasis on jewelry and capture is almost another motif of Abu Nasr's story. At the end of the story, they prefer jewelry disrespecting Khorshid and her friends who were waiting for them in Barm-e Delak. Therefore, this shows that they look at Khorshid 
and her friends as objects and nothing more. Despite the fact that Khorshid Khanom says, "So far, the four times we met, the Americans have kept their promises" (Hedayat 1963, 98). Yet, at the end of the story, Sadegh Hedayat shows otherwise to the reader. There is a point in Gorest's statement, who says that they should disarm Simuyeh so that he could not kill them. In this statement, Gorest introduces the Orientals as violent and aggressive. The Oriental ruler, Simuyeh is symptomatically presented as despotically monarchical. The inability of "Iranians" to excavate their own historical sites would seem to leave the way wide open for the importation of Dr. Warner and his friends's imperial control over them. Edward Said points out that the West has used terms and concepts such as violence and war to define the East, and it introduces itself as peaceful to the world. The point is that Simuyeh is one and these people are three.

\title{
Pleasure and Enjoyment
}

Hedayat suggests that Dr. Warner and his friends regard people of Barm-e Delak as seekers of joy and pleasure. In this story, Dr. Warner and his friends consider themselves hardworking and diligent while from their point of view the Orientals are the opposite. This is represented in the conversation between Gorset and Warner. Gorest asks Warner not to be too hard on them and let them enjoy exactly like the Orientals.

\begin{abstract}
"I want to spend a night like "Arabian Nights". Are not we in the East? Until now, except for its burning sun, which shone on our heads and its soil that we have used as eyeliners, nothing else we have obtained. "It's just that we've lived through the dead bones and the decaying objects of the old world, the sense of life has been killed in us, doctor, you've got a strange life for yourself. You study all day in the sunbathing room. At night, you do not sleep, you often get upset, talk to yourself, you have forbidden for yourself recreation and fun, and you've engaged in reading. -believe me these things make you old" (Hedayat 1963, 87).
\end{abstract}

It establishes the very important point that Dr. Warner and his friends are serious and the people of Shiraz are not and pay attention to pleasure only and that for a short period of time Gorest invites his friends to have fun. It is the contrast between the East and the West which is quite clear. The phrase "aren't we in the East?" is indicative of the fact that the East is totally associated with pleasure and a source of fun. The sentence "I want to spend a night like Arabian Nights" is reminiscent of the nineteenth-century stories that Westerners took to West through translation (Roozbeh \& Anushiravani 2016, 49). Arabian Nights tales were mostly considered emotional and obscene, and some critics such as Ziaeddin Sardar believe that "the stories of The Arabian Nights have justified Orientalism" (quoted by Roozbeh \& Anushiravani 2015, 123). The Arabian Nights in Gorest's words represent the western perspective of the East, which is emotional, superstitious, and erotic, and this shows that Hedayat has been aware of the process of Orientalism and has dealt with it in this work.

\section{Exposing the Intention of Warner through Irony}

The story of Abu Nasr's Throne has used irony. Hedayat directs this irony to Warner, who is an academician who objectively explores the Orient through scientific exploration. Instead of seeing science as his tool, since he is an archaeologist, he turns to superstition, in order to demonstrate that he is not seeking a scientific exploration, but is seeking to plunder and record the wealth of Iran. Hedayat skillfully reveals the intention of the archaeologist Warner. In fact, in this story, we see the effects of Western orientalist outlook. Hedayat has criticized in his letters the Western propaganda: "I am as embarrassed as I am of the biographies of American 
propaganda" (Dehbashi 2013, 91). Alizadeh and Afzali $(2015,23)$ have pointed to Hedayat's anti-western ideas in a short story called "Farda". This story revolves around the life of a worker called Mahdi Rezvani, known as "Zagi", who resists an American soldier who beats a woman in Iran. Zagi ultimately goes to jail for resisting the American.

\section{Knowledge Production based on the Will}

The will creates knowledge about the ancient Iran. The story may show Hedayat's interest in ancient Iran as critics have noted. However, Hedayat shows his interest in and nostalgia about the past so much so that he wants to note that this glorious past is now in the hands of the Dr. Warner and his friends to rape and plunder. The Persians and Sassanid kings, especially Simuyeh, are viewed by Dr. Warner, Freeman, and Gorest as angry, violent and aggressive beasts. This is manifested by Mr. Warner's conversation with Gorest and Freeman, whose discovery of a very important historical document made it clear to them: this historical document reveals "the inner life of a ruler in the Sassanid era". Simuyeh is ridiculed. He is called "Old Monkey", who had had three wives, and his lust is foregrounded. This point has been revealed to them from the will:

"In the name of Yazdan! I am Gorandokht, daughter of Vendesp Mogh, at the same time, sister to the king and the wife of Simuyeh, the border guard of "Barm-e Delak, Shahpesand and the white house". Ten years of our marriage passed without a child coming out of Simuyeh's seed. My husband, according to the custom and the eternal commandment, took up another wife to bring him a son. However, his efforts were in vain, as he was infertile according to doctors. Thus, Simuyeh consulted a sorceress through whim and not through religious purposes, and after using drugs, took to a vicious girl. He insisted on his decision, despite the covenant between himself and me which forbad his remarriage. He spent all his time in the White House with Khorshid, the prostitute girl. He stopped working and ruled by Khorshid and insulted me in front of her. Finally, he arranged the wedding ceremony. Not to endure scandal and humiliation, I, based on the condition I had made to Simuyeh, preferred to be buried alive, and to take my revenge, I resorted to a sorceress. The same evening, when the wedding ceremony of Simuya and Khurshid was going on, I pour the sorceress's elixir in Simuyeh's glass of wine, and he drank it and fell into the false death (Bushasp)" (Heayat 1963, 83).

In the above sentences, Simuyeh's lust has been noted. Gorundokht is viewed as emotional, superstitious, and revengeful. The magic elements are also seen in these lines. Simuyeh is considered 'old monkey'. An associative cluster of meanings relating to 'old monkey' had been added to the word's older associations with foolishness and stupidity. 'Old Monkey' links up with "lust" as Simuyeh had had three wives. The subject of studies now undergoes a change and transformation from a human being to an animal signifying the dark mirror of otherness. This begins to gain a particular imperial resonance with Dr. Warner and his friends' explorations of Iranian ethnicities:

Besides, it is proven to us the at the time of Sassanid dynasty marriage of interfamily that is marriage among family members or at least among rulers and influential figures has been prevalent, but what is important so far which we did not know is why insider every grave were several 
bones. The folks here say in ancient times when a person becomes too senile to manage on his own, the young took him outside of the city and buried him alive so much so that he could be a burden on anybody. This belief is found among some tribes of Africa with some differences. I too believed this way till now. But according to this document it is clear that every husband who died, his wives would be buried alive so that they could be his associates in the other world. This belief has existed among ancient nations (Hedayat 1963, 85).

The anthropological view of Iran is clear in the above lines. The west seeks knowledge of Iran, through which to recognize themselves. The phrase "bar ma" (to us) in the first line, as the speaker states, comes from the position of power and authority, and the verb 'is proven' reinforces this, indicating that the speaker (westerner) considers himself self-conscious and higher, and the people he studies, subordinate and inferior. The phrase 'at the time of Sassanid dynasty' gives a historical dimension to it and shows that history of Iran has been written by the West. This can strengthen Hedayat's dissatisfaction with the presence of Westerners in Iran, who like to seize the whole world and discover its history. As a Westerner, Warner puts Iranian and African cultures together and considers them similar, signifying that African and Iranian are similar. This is in tune with describing Simuyeh as an old monkey.

If the will is taken as an example of history, we will have the textuality of history since the Westerners consider the will as an important document. Thus, access to a pure and authentic past of the ancient Iran through the will, uninterrupted by the enduring textual traces of the ancient Iran is impossible, traces whose survival is not merely dependent but rather somewhat as a result of intricate and delicate social procedures of preservation and effacement; and that those textual traces are themselves affected by ensuing textual negotiations when they are understood as the "documents" upon which Warner and his assistants base their own texts, called "histories".

\section{Conclusion}

Sadeq Hedayat blended the discourses of his time in the spirit of the story. He uses his pen as a writer who writes to protest against the presence of Dr. Warner and his friends. He has inserted the issues of the day in this story and, with his imagination, illustrates the fate of Iran and its material and spiritual wealth. At the time of writing this story, Reza Khan was at the height of his power and allowed the West to come to Iran and do scientific research. He recognized these explorations and confirmed them as greatness of his own character rooted in ancient Iranian culture. He was proud of it. Every time the archeologists discovered something, he was proud of himself. Nevertheless, it is sad to see the Iranians are serving Dr. Warner and his friends as servicemen and prostitutes. Thus, Hedayat is not proud of it, and opposes it by writing itself. Hedayat shows to the reader the loss of Khorshid under Western domination. For this purpose, Hedayat chooses as his setting of the story the Qasr-i Abu Nasr and makes the story attractive to the reader through the element of suspense, tone and irony, but at the end of the story the reader is not entertained, is rather shocked. Hedayat sheds light on the plunder of Iran with a defamiliarity element and ends the story with the verb "record". 


\section{REFERENCES}

Alizadeh N. \& Afzali B. (2016). "Anti-West Beliefs in Works of Hedayat, Al-E-Ahmad And Saedi”. Persian Literature 5/2 (2016) 19-37.

Antosa S. (2012). Richard Francis Burton. Bern 2012.

Ghanoonparvar M. (2010). In a Persian Mirror: Images of the West and Westerners in Iranian Fiction. Texas 2010.

Grosz E. (1994). Volatile Bodies. Bloomington 1994.

Hedayat S. (1963). “Qasr-i Abu Nasr”. Alaviyah Khanum va Valangary (1963) 81-109. Teheran 1963.

Kamshad H. (2011). Modern Persian Prose Literature. Cambridge 2011.

Katouzian H. (1996). Sadeq Hedayat: The Life and Legend of an Iranian Writer. IB Tauris 2002.

Lewis R. (1996) Gendering Orientalism. London 1996.

Roozbeh K. \& Anoushirovani R. A. (2016). "Thousands and One Nights from the Perspective of Literary Adaptation”. Letter of Comparative Literature. 6/22 (2016) 49-69.

Roozbeh K. R. \& Anushirvani A. (2015). "Representation of the Orient in Pasolini's Arabian Nights". International Letters of Social and Humanistic Sciences 58 (2015) 123-129.

Whitcomb D. S. (1985). Before the Roses and Nightingales: Excavations at Qasr-i Abu Nasr, Old Shiraz. Metropolitan Museum of Art, 1985.

Zarrin A. (1997). "The Rhetoric of Self and Other in Selected Iranian Short Stories, 19061979”. International Fiction Review 1/2 (1997) 24. 